\title{
ABO blood group and ischaemic heart disease in British men
}

\author{
P H Whincup, D G Cook, A N Phillips, A G Shaper
}

\begin{abstract}
Objective-To establish whether ABO blood group is related to ischaemic heart disease on an individual and geographic basis in Britain.

Design-Prospective study of 7662 men with known ABO blood group selected from age-sex registers in general practices in 24 British towns.

Measurements-ABO blood group, standard cardiovascular risk factors, social class, and presence or absence of ischaemic heart disease determined at entry to study.

End points - Eight year follow up of fatal and nonfatal ischaemic heart disease events achieved for $99 \%$ of study population.

Results - Towns with a higher prevalence of blood group $\mathbf{O}$ had higher incidences of ischaemic heart disease. In individual subjects, however, the incidence of ischaemic heart disease was higher in those with group $A$ than in those with other blood groups (relative risk $1 \cdot 21,95 \%$ confidence limits 1.01 to 1.46). Total serum cholesterol concentration was slightly higher in subjects of blood group $A$. No other cardiovascular risk factor (including social class) was related to blood group.

Conclusions-Blood group A is related to the incidence of ischaemic heart disease in individual subjects. Geographic differences in the distribution of ABO blood groups do not explain geographic variation in rates of ischaemic heart disease in Britain. The findings do not support the view that ABO blood group and social class are related.
\end{abstract}

\section{Introduction}

Several reports have suggested that ABO blood type is associated with the risk of ischaemic heart disease. Case-control studies comparing the prevalence of $\mathrm{ABO}$ groups in survivors of myocardial infarction with that in male blood donors ${ }^{12}$ and female controls in hospital ${ }^{3}$ found that the prevalence of blood group $\mathrm{A}$ was greater than expected in subjects with myocardial infarction. Results from the Framingham study and the Israeli ischaemic heart disease project have indicated that the incidence of ischaemic heart disease may be higher in subjects of blood group A or its subgroups than other blood groups. ${ }^{+5}$ In apparent contradiction, Mitchell showed that towns with a higher prevalence of blood group $\mathrm{O}$ had higher rates of cardiovascular mortality. $\mathrm{He}$ suggested that cardiovascular disease might be more lethal in subjects with blood group $\mathrm{O}$ and that the differences in the distribution of blood group $\mathrm{O}$ in different parts of Britain might provide an explanation for the geographic variation in ischaemic heart disease.

We used data from the British regional heart study, a prospective study of ischaemic heart disease in a representative sample of middle aged men drawn from 24 British towns, to explore the relation between $\mathrm{ABO}$ blood group and ischaemic heart disease in towns and individual subjects. We also examined the relation between $\mathrm{ABO}$ blood group and cardiovascular risk factors. Social class was included because of the controversy produced by a recent suggestion that blood group A may be associated with higher social class. $^{78}$

\section{Subjects and methods}

The British regional heart study examined 7735 men (response rate $78 \%$ ) aged $40-59$ randomly selected from the age-sex registers of group general practices in 24 towns in England, Wales, and Scotland. The criteria for selecting the towns, general practices, and subjects, as well as the methods of data collection, have been presented in detail in previous reports. ${ }^{912}$ The towns, generally with populations of $50000-100000$, were selected to represent the full range of cardiovascular disease mortality and included towns in all major standard regions. The general practice selected in each town was required to have a social class distribution among men representative of that town. Men with preexisting cardiovascular disease were not excluded. The analyses presented here are restricted to 7662 subjects in whom $\mathrm{ABO}$ blood group was known.

\section{RISK FACTORS}

ABO blood groups were determined by standard agglutination techniques. Estimations of serum total cholesterol concentrations were carried out by a modified Liebermann-Burchard method. High density lipoprotein cholesterol concentration was measured after magnesium-phosphotungstate precipitation, initially by applying the Liebermann-Burchard method (11 towns) and subsequently by an enzymatic procedure. ${ }^{13}$ Blood pressure values at initial screening were based on the mean of two successive readings taken with the London School of Hygiene sphygmomanometer with the subject seated and the arm supported on a cushion. All blood pressure readings were adjusted for observer variation within each town. ${ }^{14}$ Systolic blood pressure is presented here because it is a stronger predictor of cardiovascular risk than diastolic pressure. ${ }^{15}$ The number of years a man had smoked cigarettes ("smoking years") is presented for current and former smokers because it is a strong predictor of risk of ischaemic heart disease. ${ }^{16}$ Social class was determined by asking each man about his longest held occupation, which was then coded in accordance with the registrar general's occupational classification. ${ }^{17}$ The analyses of social class presented here exclude 227 men whose longest held occupation was in the armed services and 14 for whom insufficient data were available.

\section{PRE-EXISTING ISCHAEMIC HEART DISEASE}

The presence of pre-existing ischaemic heart disease at screening was defined as the presence of one or more of: a history suggesting angina or myocardial infarction from a standard WHO (Rose) chest pain requests for reprints to: Dr Whincup. 
questionnaire $^{11}$; an electrocardiogram showing electrocardiographic evidence of possible or definite previous myocardial infarction or definite myocardial ischaemia ${ }^{11}$; and the patient's recall of a doctor's diagnosis of angina or myocardial infarction.

\section{FOLLOW UP PROCEDURES}

All men who took part in the original examination were followed up for mortality and morbidity from cardiovascular disease over eight years. The study therefore included men with evidence of pre-existing heart disease; analyses of follow up presented in this paper include these subjects. Follow up was achieved for $99 \%$ of the original cohort. ${ }^{18}$ The analyses reported here are based on the first major ischaemic heart disease events (myocardial infarction or death) during the follow up period for each patient. The rate of these events will be referred to as the ischaemic heart disease incidence rate, calculated in this instance with subjects with pre-existing ischaemic heart disease included. The results presented are based on first events after screening in $481(6.3 \%)$ of the original 7662 men; 176 first events were fatal.

CASE DEFINITIONS FOR MAJOR ISCHAEMIC HEART DISEASE

The following definitions were used to determine whether any reported cardiovascular event during follow up could be accepted as an episode of new major ischaemic heart disease.

Non-fatal-Any report of myocardial infarction accompanied by at least two of: a history of severe chest pain; electrocardiographic evidence of myocardial infarction; and cardiac enzyme changes associated with myocardial infarction. Subjects who died and had evidence of new myocardial infarction more than 28 days after the onset of the first event were included in this non-fatal group. ${ }^{19}$

Fatal-Any subject in whom the death certificate recorded ischaemic heart disease (International Classification of Diseases codes 410-414) as the cause of death and in whom this statement was not contradicted either by the medical history or by findings at necropsy. Sudden death for which no other cause was apparent and which was certified as due to ischaemic heart disease was included in this category.

Case fatality is defined as the proportion of these major ischaemic heart disease events in which death occurred during the clinical course of the event and in which the death certificate recorded ischaemic heart disease (ICD codes 410-414).

\section{STATISTICAL METHODS}

Differences in the prevalence of and event rates for ischaemic heart disease between $\mathrm{ABO}$ blood groups were assessed using $\chi^{2}$ tests across all groups (test of heterogeneity) and, where indicated, comparing one group with the other three. An exact test (two sided) was used to compare case fatality rates between groups because values of less than five were expected in group $\mathrm{AB}$. Confidence intervals for relative risks were calculated using Woolf's method. ${ }^{20} \mathrm{ABO}$ differences in cardiovascular risk factors were examined using one

TABLE I-ABO blood group and the prevalence, incidence, and case fatality of ischaemic heart disease

\begin{tabular}{|c|c|c|c|c|c|}
\hline & \multicolumn{4}{|c|}{ Blood group } & \multirow[b]{2}{*}{ Total } \\
\hline & A & B & $\mathrm{AB}$ & $\mathrm{O}$ & \\
\hline No (\%) of men in each $A B O$ group & $3150(41 \cdot 1)$ & $718(9 \cdot 4)$ & $222(2 \cdot 9)$ & $3572(46 \cdot 6)$ & $7662(100)$ \\
\hline $\begin{array}{l}\text { No }(\%) \text { of men with ischaemic heart } \\
\text { disease at examination }\end{array}$ & $796(25$ & $199(28)$ & $49(22)$ & $906(25)$ & $1950(25)$ \\
\hline $\begin{array}{l}\text { No of patients with ischaemic heart } \\
\text { disease events } \\
\text { Incidence of ischaemic heart disease }\end{array}$ & 219 & 49 & 11 & 202 & 481 \\
\hline $\begin{array}{l}\text { events }{ }^{\star}(1000 / \text { year }) \\
\% \text { (No) of fatal cases }\end{array}$ & $\begin{array}{c}8 \cdot 7 \\
34(7+\end{array}$ & $\begin{array}{c}8 \cdot 5 \\
45(22)\end{array}$ & $\begin{array}{c}6 \cdot 2 \\
45(5)\end{array}$ & $\begin{array}{c}7 \cdot 1 \\
37(75)\end{array}$ & $\begin{array}{l}7 \cdot 8 \\
37(176)\end{array}$ \\
\hline
\end{tabular}

way analysis of variance, with the exception of social class, where a $\chi^{2}$ test was used.

\section{Results}

VARIATION IN ABO BLOOD GROUPS BETWEEN TOWNS AND ITS RELATION TO ISCHAEMIC HEART DISEASE

The proportions of study participants with different $\mathrm{ABO}$ blood groups (table I) reflect the well known predominance of blood groups $\mathrm{A}$ and $\mathrm{O}$ and are very similar to estimates for Britain as a whole. ${ }^{21}$ The prevalence of blood group $\mathrm{O}$ varied between towns (fig 1), ranging from $40 \%$ (Guildford) to 52\% (Ayr). Overall, the prevalence of blood group $\mathrm{O}$ was lower in southern and eastern England than in north western and northern England and Scotland, which agrees with earlier reports. ${ }^{22}$ There is still considerable variation within regions, which may be explained at least in part by sampling variation due to the small numbers of subjects in each town (average 319).

The geographic relation between blood group $\mathrm{O}$ and the incidence of major ischaemic heart disease events in the 24 study towns is presented in figure 2 . A strong

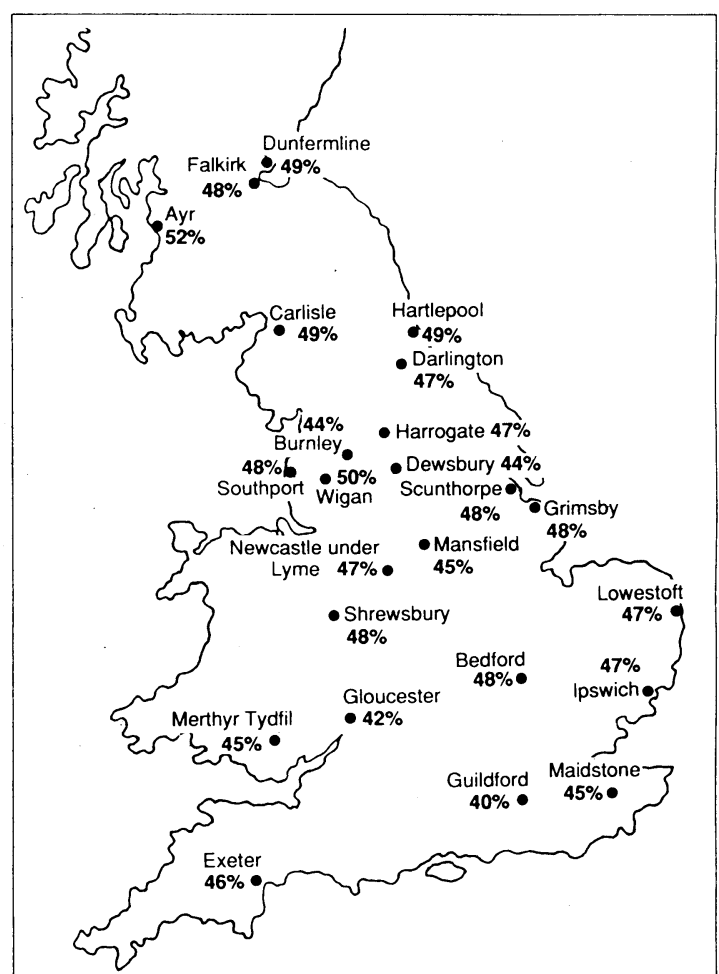

FIG 1 -Prevalence of blood group $O$ in middle aged men in 24 towns of British regional heart study

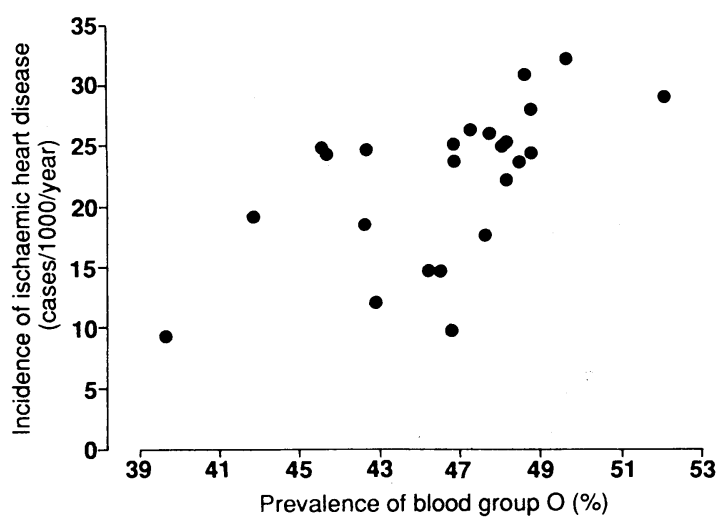

FIG 2-Prevalence of blood group $O$ and annual incidence of ischaemic heart disease per thousand in 24 British towns during eight year follow up in British regional heart study. Incidence is rate of first major ischaemic heart disease events during follow up and includes subjects with pre-existing ischaemic heart disease 


\begin{tabular}{|c|c|c|c|c|c|}
\hline & \multicolumn{4}{|c|}{ Blood group } & \multirow[b]{2}{*}{$\begin{array}{c}\text { Test for } \\
\text { heterogeneity }\end{array}$} \\
\hline & $\underset{(n=3150)}{\mathrm{A}}$ & $\underset{(\mathbf{n}=718)}{\mathrm{B}}$ & $\begin{array}{c}\mathrm{AB} \\
(\mathbf{n}=222)\end{array}$ & $\underset{(\mathrm{n}=3572)}{\mathrm{O}}$ & \\
\hline \multirow{2}{*}{$\begin{array}{l}\text { Mean }(\mathrm{SE}) \text { age (years) } \\
\text { Mean }(\mathrm{SE}) \text { serum total cholesterol } \\
\text { concentration }(\mathrm{mmol} / \mathrm{l})\end{array}$} & $50 \cdot 2(0 \cdot 1)$ & $50 \cdot 5(0 \cdot 2)$ & $50 \cdot 0(0 \cdot 4)$ & $50 \cdot 2(0 \cdot 1)$ & $p=0.63$ \\
\hline & $6.37(0 \cdot 02)$ & $6 \cdot 25(0 \cdot 04)$ & $6.34(0.07)$ & $6 \cdot 24(0 \cdot 02)$ & $\mathrm{p}<0.001$ \\
\hline \multirow{3}{*}{$\begin{array}{l}\text { Mean }(\mathrm{SE}) \text { systolic blood pressure } \\
(\mathrm{mm} \mathrm{Hg}) \\
\text { Mean }(\mathrm{SE}) \text { years smoking } \\
\text { Mean }(\mathrm{SE}) \text { high density lipoprotein } \\
\text { cholesterol concentration } \\
(\mathrm{mmol} / \mathrm{l})\end{array}$} & $145 \cdot 7(0 \cdot 4)$ & $144 \cdot 2(0 \cdot 7)$ & $144 \cdot 3(1 \cdot 4)$ & $145 \cdot 0(0 \cdot 4)$ & $\mathrm{p}=0.21$ \\
\hline & $20 \cdot 5(0 \cdot 3)$ & $20.5(0.6)$ & $20 \cdot 4(1 \cdot 1)$ & $21 \cdot 0(0 \cdot 3)$ & $\mathrm{p}=0.54$ \\
\hline & $1 \cdot 14(0 \cdot 00)$ & $1 \cdot 15(0.01)$ & $1 \cdot 18(0 \cdot 02)$ & $1.15(0.00)$ & $\mathrm{p}=0 \cdot 18$ \\
\hline $\begin{array}{l}\% \text { (No) from social classes III } \\
\text { manual, IV, and } V^{\star}\end{array}$ & $57(1755 / 3058$ & $61(420 / 690)$ & $63(136 / 216)$ & $60(2075 / 3457)$ & $\mathrm{p}=0.25$ \\
\hline
\end{tabular}

${ }^{\star}$ Excludes 231 men with longest held occupation in armed services and 15 with occupation not known.

TABLE III - ABO blood group and social class. Values are percentages (numbers)

\begin{tabular}{|c|c|c|c|c|}
\hline & \multicolumn{4}{|c|}{ Blood groups } \\
\hline & A & B & $\mathrm{AB}$ & $\mathrm{O}$ \\
\hline I (Professional $)(n=603)$ & $41 \cdot 5(250)$ & $9 \cdot 5(57)$ & $2 \cdot 8(17)$ & $46 \cdot 3(279)$ \\
\hline II $($ Intermediate $)(\mathrm{n}=1721)$ & $42 \cdot 7(735)$ & $8 \cdot 7(149)$ & $2.5(43)$ & $46 \cdot 1(794)$ \\
\hline III non-manual (Clerical) $(\mathrm{n}=711)$ & $44 \cdot 7(318)$ & $9 \cdot 0(64)$ & $2 \cdot 8(20)$ & $43.5(309)$ \\
\hline III manual (Skilled) $(\mathrm{n}=3291)$ & $40 \cdot 1(1319)$ & $9 \cdot 4(309)$ & $2 \cdot 9(95)$ & $47 \cdot 6(1568)$ \\
\hline IV (Semiskilled) $(n=781)$ & $40.0(312)$ & $9 \cdot 7(76)$ & $3.6(28)$ & $46 \cdot 7(365)$ \\
\hline $\mathrm{V}($ Unskilled $)(\mathrm{n}=314)$ & $39 \cdot 5(124)$ & $11 \cdot 1(35)$ & $4 \cdot 1(13)$ & $45 \cdot 2(142)$ \\
\hline Total $(n=7421)$ & $41 \cdot 2(3058)$ & $9 \cdot 3(690)$ & $2 \cdot 9(216)$ & $46 \cdot 6(3457)$ \\
\hline
\end{tabular}

positive association between the proportion of subjects with blood group $\mathrm{O}$ in a town and the rate of first ischaemic heart disease events in that town is shown $(\mathrm{r}=0.58 ; \mathrm{p}=0.003)$. To explore this relation, which is similar to that observed by Mitchell for mortality from atherosclerotic and coronary heart disease,${ }^{6}$ the relations between $\mathrm{ABO}$ blood group and the prevalence, incidence, and case fatality rate of ischaemic heart disease were examined in individual subjects.

\section{ABO BLOOD GROUP AND ISCHAEMIC HEART DISEASE IN INDIVIDUAL SUBJECTS}

Prevalence-There is little difference in prevalence between the different $\mathrm{ABO}$ groups (table $\mathrm{I} ; \chi_{3}^{2}=3.35$, $\mathrm{p}=0.34$ ). In particular, the prevalence was identical in blood groups A and O. Although subjects of blood group $\mathrm{B}$ seem to have a slightly higher prevalence than average and subjects with group $\mathrm{AB}$ a slightly lower prevalence, these differences could easily be due to chance.

Incidence-Differences in incidence between $\mathrm{ABO}$ groups (table I) were small and did not achieve significance in tests of heterogeneity over all four groups $\left(\chi_{3}^{2}=5 \cdot 82 ; p=0 \cdot 12\right)$. The incidence in subjects of blood group A was, however, marginally higher than that of blood group $\mathrm{O}$. When blood group $\mathrm{A}$ was compared with the other three groups the relative risk was $1.21(95 \%$ confidence interval 1.01 to $1 \cdot 46)$. The relative risk of first ischaemic heart disease events in subjects of blood group $\mathrm{O}$ compared with the other three groups was 0.82 ( $95 \%$ confidence interval 0.68 to $0.99)$. These findings were not affected by excluding prevalent cases. Incidence rates in subgroups of blood group $\mathrm{A}$ and $\mathrm{AB}$ were also examined. The highest rate was observed in blood group $A_{1}(9 \cdot 21$ cases/1000/year), but this was not significantly different from those in other $\mathrm{A}$ and $\mathrm{AB}$ subgroups (exact test for heterogeneity, $\mathrm{p}=0.83$ ).

Case fatality-There was some variation in case fatality rates between $\mathrm{ABO}$ groups (table I), but there was no consistent difference in case fatality rates between blood group A and the other groups, or between blood group $\mathrm{O}$ and other groups. The slight excess observed in subjects of group B did not approach significance in a test across the four blood groups $(\bar{p}=0 \cdot 4)$. These findings were not affected by excluding prevalent cases.
FACTORS

Table II shows the relation between blood group and major cardiovascular risk factors. As the mean ages of subjects with different blood groups were extremely similar no adjustment for age was carried out. Total cholesterol concentrations were higher in group $\mathrm{A}$ and to a lesser extent in group $\mathrm{AB}$ than in groups $\mathrm{B}$ and $\mathrm{O}$. Although the differences were small (with a range of $0.13 \mathrm{mmol} / \mathrm{l}$ ), the variation between groups was highly significant (one way analysis of variance, $p<0.001$ ) and persisted after adjustment for the effect of town. The small differences between $\mathrm{ABO}$ groups in blood pressure, smoking years, and high density lipoprotein cholesterol concentrations were not significant.

The proportion of subjects in manual occupations was slightly smaller in subjects of blood group A than in other blood groups. However, the variation in the proportion of manual workers was not significant either in a global test among all four groups $(p=0 \cdot 25)$ or in a comparison of group $A$ and the other three groups $(p=0 \cdot 07)$. Because there has been considerable interest in the possibility of a relation between blood group and social class the distribution of $\mathrm{ABO}$ blood groups in the six social classes is presented in table III. It can be seen that the slightly higher proportion of subjects of blood group A in non-manual occupations is accounted for almost entirely by class III nonmanual. The proportion of subjects of group A in classes I and II was close to the average and there was no evidence of a consistent trend in the prevalence of blood group A across the six social classes $(p>0 \cdot 25)$. Similarly, the prevalence of the other common blood group, $\mathrm{O}$, showed no evidence of a consistent relation with social class.

ABO GROUP DIFFERENCES IN TOTAL SERUM CHOLESTEROI AND INCIDENCE OF ISCHAEMIC HEART DISEASE

We examined the contribution of the higher total serum cholesterol concentration in subjects of blood group A to differences in the incidence of ischaemic heart disease between group A and other groups. When the effect of total serum cholesterol differences was taken into account the relative risk associated with blood group A fell from $1 \cdot 21$ to $1 \cdot 16$ (95\% confidence interval 0.96 to $1 \cdot 40$ ).

\section{Discussion}

ABO BLOOD GROUP AND ISCHAEMIC HEART DISEASE IN INDIVIDUAL SUBJECTS

The results suggest that blood group $\mathrm{A}$ is associated with a slightly higher incidence of ischaemic heart disease events in these middle aged British men. However, the estimated relative risk is small $(1 \cdot 21$ with an upper $95 \%$ confidence limit of $1 \cdot 46$ ), which suggests that the effect is not likely to be clinically important. The finding is consistent with the results of case-control studies (comparing survivors of myocardial infarction with blood donors or other hospital patients), which reported relative risks associated with blood group $\mathrm{A}$ of 1.2 and 1.52 in men ${ }^{12}$ and 1.5 in women. ${ }^{3}$ It is also consistent with the report on incidence of ischaemic heart disease over four years for men in the Framingham study, ${ }^{+}$which did not, however, show a similar pattern for women.

The results did not provide convincing evidence that any of the A subgroups were strongly associated with a high incidence of ischaemic heart disease. In particular, they provided no support for the higher rate of ischaemic heart disease in group $A_{1} B$ observed in the Israeli heart disease project. ${ }^{5}$ The differences in ischaemic heart disease rates between subgroups of group A in that study were small, and the statistical 
significance of the finding was marginal even in a retrospective comparison with all other blood groups.

ABO BLOOD GROUP AND TOTAL SERUM CHOLESTEROL

In the analyses of the relation between $\mathrm{ABO}$ blood group and major cardiovascular risk factors the only association of note was that between blood group $A$ and serum total cholesterol concentration. This relation, although highly significant, was small in magnitude (mean difference $0 \cdot 124 \mathrm{mmol} / \mathrm{l}$ between group A and other groups). The findings are consistent with those of two previous reports. ${ }^{2324}$

The higher concentrations of total serum cholesterol in subjects of blood group A seemed to contribute to the slightly higher incidence of ischaemic heart disease events in subjects of this group. The results do not, however, allow a firm conclusion as to whether cholesterol explains all or only part of the differences in the incidence of ischaemic heart disease between group A and the other groups.

\section{ABO BLOOD GROUP AND SOCIAL CLASS}

The relation between $\mathrm{ABO}$ blood group and social class was examined in some detail because of the report by Beardmore and Karimi-Booshehri, ${ }^{7}$ who examined the relation between blood group and social class in 9691 blood donors from Yorkshire and south west England and reported an excess of blood group A among social classes I and II. Although there was a slightly higher proportion of subjects with blood group $A$ in non-manual occupations in our sample than would have been expected, this excess did not reach significance either in a test of heterogeneity across all four blood groups or in a test between group $\mathrm{A}$ and the other three groups. Moreover, in our data the highest proportion of subjects with blood group A was seen in social class III non-manual; there is no suggestion of a trend of increasing proportions of subjects of blood group $\mathrm{A}$ in the intermediate and professional groups. Although our data set is slightly smaller than that of Beardmore and Karimi-Booshehri, it may provide a more representative sample of the population than does the blood donor sample described by these authors. In particular, their sample contained a remarkably high proportion of subjects of social classes IV (19.3\%) and $\mathrm{V}(24 \cdot 7 \%)$, which are usually underrepresented in blood donor populations. ${ }^{25} \mathrm{~A}$ recent report from an Irish regional blood bank, with a smaller proportion of subjects in social class $\mathrm{V}$, found no relation between $\mathrm{ABO}$ blood group and social class. ${ }^{26}$

\section{GEOGRAPHIC DIFFERENCES IN ABO BLOOD GROUP AND ISCHAEMIC HEART DISEASE}

The variation in heart disease rates within Britain has been the source of much interest. The results presented in figure 2 imply that the prevalence of blood group $\mathrm{O}$ is related to the incidence of ischaemic heart disease events on a town basis, consistent with Mitchell's observations for mortality. ${ }^{6}$ If this association is of aetiological importance blood group $\mathrm{O}$ should be related to the occurrence of ischaemic heart disease in individual subjects. The results of the analyses between $\mathrm{ABO}$ blood group and ischaemic heart disease suggest that there is no such association; the incidence of ischaemic heart disease was, if anything, higher in subjects with blood group $\mathrm{A}$, and there was no important difference in case fatality rates between blood groups. This implies that the association between blood group $\mathrm{O}$ and ischaemic heart disease found at the town level in purely an ecological correlation and cannot explain the geographic differ- ences in ischaemic heart disease within Britain.

These results do not deny the potential importance of genetic factors in the aetiology of ischaemic heart disease. They do, however, suggest that the contribution of $\mathrm{ABO}$ blood groups and associated factors to individual risk is small. They also imply that geographic differences in the distribution of blood group $\mathrm{O}$ are not responsible for geographic variation in the occurrence of heart disease within Britain. In this respect the results are consistent with a recent report from the British regional heart study describing the relation between migration and ischaemic heart disease in Britain, which suggests that geographic differences in the incidence of cardiovascular disease are acquired rather than inherited..$^{27}$

The British regional heart study is a British Heart Foundation research group and is also supported by the Medical Research Council, the Chest, Heart and Stroke Association, and the Department of Health. ABO blood group analyses were carried out in the West Midlands Regional Blood Transfusion Unit under the supervision of Dr R N Ibbotson. Biochemical analyses were carried out in the Wolfson Research Laboratories, Birmingham (Professor T P Whitehead). PHW is supported by a Wellcome Trust training fellowship in clinical epidemiology.

1 Allan TM, Dawson AA. ABO blood groups and ischaemic heart disease in men. Br Heart f 1968;30:377-82

Bronte-Stewart $\mathrm{B}$, Botha $\mathrm{MC}$. ABO blood groups in relation to ischaemic hear disease. Br Med f 1962;i:1646-50.

3 Rosenberg L, Miller DR, Kaufman DW, et al. Myocardial infarction in women under 50 years of age. $7 A M A$ 1983;250:2801-6.

4 Havlik RJ, Feinleib M, Garrison RJ, Kannel WB. Blood groups and coronary heart disease Lancet 1969:ii:269-70.

5 Medalie JH, Levene C, Papier C, et al. Blood groups, myocardial infarction and angina pectoris among 10000 adult males. N Engl F Med 1971;285: 1348-53.

6 Mitchell JRA. An association between $\mathrm{ABO}$ blood-group distribution and geographical differences in death-rates. Lancet 1977; i:295-7.

Beardmore JA, Karimi-Booshehri F. ABO genes are differentially distributed in socio-economic groups in England. Nature 1983;303:522-4.

8 [Commentary.] Blood group and social class. Nature 1984:309:395-9.

Shaper AG, Pocock SJ, Walker M, Cohen NM, Wale CJ, Thomson AG British regional heart study: cardiovascular risk factors in middle aged men in 24 towns. Br.Med f 1981;283:179-86.

10 Shaper AG, Pocock SJ, Phillips AN, Whitehead TP, Macfarlane PW. Risk factors for ischaemic heart disease: the prospective phase of the British regional heart study. I Epidemiol Community Health 1985;39:197-209.

11 Shaper AG, Cook DG, Walker M, Macfarlane PW. Prevalence of ischaemic heart disease in middle-aged British men. Br Heart 7 1984;51:595-605.

12 Shaper AG, Cook DG, Walker M, Macfarlane PW. Recall of diagnosis by men with ischaemic heart disease. Br Heart f 1984;51:606-11.

13 Lopes-Virella MF, Stone P, Ellis S, Colwell JA. Cholesterol determination in high-density lipoproteins separated by three different methods. Clin Chem 1977:23:882-4.

14 Bruce NG, Shaper AG, Walker M, Wannamethee G. Observer bias in blood pressure studies. $\mathcal{F}$ Hypertens 1988;6:375-80.

15 Shaper AG, Phillips AN, Pocock SJ, Walker M. Systolic and diastolic blood pressure in the prediction of heart attack and stroke [Abstract]. f Hypertens 1987;5:76

16 Cook DG, Shaper AG, Pocock SJ, Kussick S. Giving up smoking and the risk of heart attack. Lancet 1986;ii: 1376-80.

17 Office of Population Censuses and Surveys. Classification of occupations London: HMSO, 1980

18 Walker M, Shaper AG. Follow-up of subjects in prospective studies in general practice. 7 R Coll Gen Pract 1984:34:365-70.

19 World Health Organisation. Proposal for the multinational monitoring of trend and determinants in cardiovascular disease (MONICA) project and protocol.
Geneva: Cardiovascular Diseases Unit, World Health Organisation, 1983.

20 Armitage P, Berry G. Statistical methods in medical research. Oxford Blackwell Scientific, 1987:456-68.

21 Bird GWG, Tover GH. The blood groups. In: Hardisty RM, Weatherall DJ, eds. Blood and its disorders. 2nd ed. Oxford: Blackwell Scientific, 1982: eds. Blood an

$22 \mathrm{Kopec} \mathrm{AC}$. The distribution of the blood groups in the United Kingdom. Oxford: Oxford University Press, 1970

23 Langman MJS, Elwood PC, Foote J, Ryrie DR. ABO and Lewis blood group and serum cholesterol. Lancet 1969;ii:607-9.

24 Oliver MF, Geizerova H, Cumming RA, Heady JA. Serum cholesterol an $\mathrm{ABO}$ and rhesus blood groups. Lancet 1969;ii:605-7.

25 Titmuss RM. The gift relationship: from human blood to social policy. London: George Allen and Unwin, 1970

26 Kelleher C, Cooper J, Sadlier D. ABO blood group and social class: a prospective study in a regional blood bank. 7 Epidemiol Community Health 1990;44:59-61.

27 Elford J, Phillips AN, Thomson AG, Shaper AG. Migration and geographic variations in ischaemic heart disease in Great Britain. Lancet 1989;i:343-6.

(Accepted 3 April 1990) 